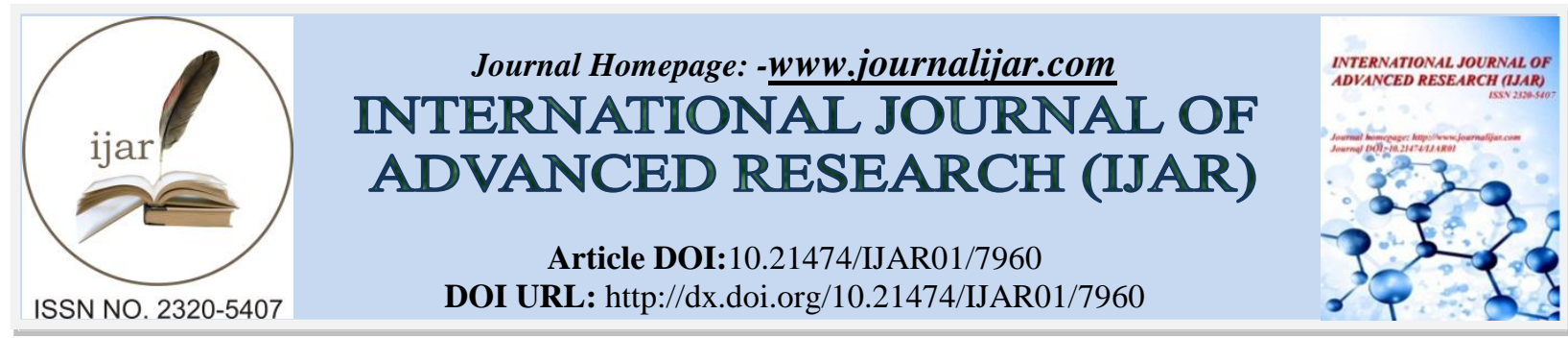

RESEARCH ARTICLE

\title{
MICROFLORA OF SOIL: A REVIEW.
}

Harleen Kaur Talwar ${ }^{1}$ and Anshu Sibbal Chatli ${ }^{2}$.

1. Department of Biotechnology, Guru Nanak Girls college, Model Town, Ludhiana.

2. Department of Microbiology, Guru Nanak Girls college, Model Town, Ludhiana.

\section{Manuscript Info}

Manuscript History

Received: 17 August 2018

Final Accepted: 19 September 2018

Published: October 2018

Keywords:-

Soil,Ecosystem,Microorganisms

\begin{abstract}
Microflora of soil is an integral part of soil Organic Matter. Soil bacteria and fungi are the start of the soil food web that supports other organisms. Bacteria constitute the most abundant groups of microorganisms in soil and the fungal population of soils constitutes a very heterogenous group of organisms. The bacterial genera Nocardia, Streptomyces and Micromonospora belong to order actinomycetes (aerobic and heterotrophic) are capable of degrading many complex organic substances and consequently play an important role in building soil fertility. The soil food web is interconnected matrix of invisible (fungi, bacteria, protozoa, nematodes) and visible (earthworms, beetles, arthopods) creatures that have a whole host of functions which creates a healthy ecosystem for plant growth. Various microorganisms were isolated from different soil samples collected. Thus the population of total bacteria in rhizosphere was reported to be highest as compared as to non-rhizosphere. The majority of the bacteria were reported to be Bacillus and Micrococcus Species. The total fungal population densities were also decreased in non-rhizosphere while the highest fungal population was observed in rhizosphere. The majority of fungi were reported to be Aspergillus niger, Aspergillus fumigatus, Penicillum species and Fusarium species. A number of diazotrophs bacteria have abilities to fix Nitrogen, some strains may relieve deficiencies where there is an inadequate application of $\mathrm{N}$ fertilizers. Many heterotrophic bacteria live in the soil and fix significant levels of Nitrogen including Azotobacter, Azospirillum and Rhizobium. N fixing microorganisms are globally noteworthy due to the fact as they provide only natural biological source of fixed $\mathrm{N}$ in the biosphere. The population count of Azotobacter was also more in rhizosphere than non-rhizosphere sites.
\end{abstract}

Copy Right, IJAR, 2018,. All rights reserved.

\section{Introduction:-}

Microorganisms are involved in biogeochemical cycling of nutrients, humus synthesis and breakdown, soil aggregation, stabilization and mobilization and transfer of mineral nutrients from soil to plants. Nitrogen $(\mathrm{N})$ is a critical nutrients required for enhancing plant growth and ultimately crop production. Due to environmental pollution and plant toxicity caused by the heavy use of chemical fertilizers, the active approach is driven for development of biofertilizers by Nitrogen fixing microbes and Phosphate solubilizing microbes too (Mazid et al, 
2014). These microbial inoculants have become a hope for most countries, as far as economical and environmental view points are concerned. These beneficiary microorganisms are better alternatives for reclamation of wastelands when compared with chemical fertilizers. They can improve soil texture, structure and proliferate useful soil microorganisms.

\section{Soil As A Habitat For Microorganisms}

Soil forms the most important medium for the survival, growth and multiplication of microorganisms (Jacoby et al, 2017). The physical and chemical characterstics of a soil are different in different parts of the soil profile. The plant and animal residues which remain deposited in soil contribute organic substances in it. These microorganisms affect soil structure and fertility. Soil microorganisms are classified into bacteria, actinomycetes, fungi, algae and protozoa. Each of these groups have characterstic functions in soils (Mendes et al, 2013).The population of these microbes is highest in rhizosphere zone than that of other zones due to production of growth promoting substances by plants. Soil microorganisms breakdown a variety of organic materials and use a portion of these breakdown products to generate or synthesize a series of compounds that make humus, a dark coloured amorphous substance, polysaccharides, non-humic substances and humin (Yan and Qin, 2015). These materials effect on the physical, chemical and biochemical properties of soil in many ways. Humus improves the texture and structure of the soil, contributes to its buffering capacity and increases the water holding capacity of soil. Autotrophic bacteria are more in number in soil as compared to heterotrophic bacteria as autotrophs derive their energy by making their own food through oxidation (Nitrobacter species) rather than feeding on plants and other species. These bacteria play an important role in nitrogen fixation. PGPR viz. Pseudomonas plays an important role in antagonism. The bacteria are especially more numerous than the other major groups of organisms in soil. In well aerated soils, both bacteria and fungi dominate, whereas bacteria alone account for almost all the biological and chemical changes in environment containing little or no oxygen. The abundance of microbial population varies with the soil conditions, such as soil structure, $\mathrm{pH}$ and other environmental parameters. Soil microbial activity is also influenced by chemical fertilizers, organic amendments and other cropping practices such as application of plant protection chemicals. These chemical fertilizers could affect the quantity and quality of microbial population.

Clark (1949) suggested that the soil microflora is highest in rhizosphere as the highest microbial activity is found in this region only.

Agnihotrudu (1953) while studying the Rhizosphere microflora of Pigeon pea, Cluster bean, French bean reported higher number of bacteria in the rhizosphere than in non-leguminous plants.

Mosolov et al (1959) reported an increase in the microflora populations of both rhizosphere and non-rhizosphere soil enriched with NPK fertilizer.

For isolation and enumeration of total number of cultivable heterotrophs, $\mathrm{N}$ fixing, PSB and cellulolytic microorganisms, the plating dilution technique was used. Plates were incubated at $30^{\circ} \mathrm{C}$ for $3-7$ days and colony forming units (cfu) were counted. The statistical analysis of enumeration of microorganisms isolated on the agar medium were carried out (Ashmarin and Vorobyev, 1962).

The prevalence of phytohormones producing bacteria in wheat rhizosphere was reported by Riviere (1963). There are many reports to show that the quality and quantity of microorganisms present in rhizosphere of disease resistant crop varieties are significantly different from those susceptible varities. In some cases, organisms specifically anatagonising the concerned pathogen have been isolated from the rhizosphere of resistant crop varities, but not from susceptible ones.

Vasantharajan and Bhat (1967) reviewed the work on interaction of soil microorganisms and mulberry roots and discussed that rhizosphere isolates were more active in phytohormone synthesis than their soil counter parts.

Fries (1973) discussed that the volatile organic compounds from living roots affected the growth and development of fungi

The total number of microorganisms in the rhizosphere and the rhizoplane of the certain plants viz. $P$. astralia and Madia sativa was determined by dilution plate technique using nutrient agar (Backer et al, 1997). 
The increase of rhizosphere microbial population was reported during vegetative development while the same decreased with root senescence (Baber and Lynch 1977).

Rahim et al (1983) studied the qualitative and quantitative aspects of rhizosphere microflora from sugarcane (Saccharum officinarum). The population of fungi (Aspergillus, Rhizopus, Fusarium and Mycelium) was reported to be highest in rhizosphere.

The soil in which plants grow varies widely in its Physical and Biological properties. Several factors influence plant growth, both directly and indirectly. Soil being loaded with millions of microorganisms influences the plant growth. As a result interaction between the soil and plant microbes become distinct and dynamic (Rangaswami, 1988).

Roal and Vaidya (1988) working with rhizosphere and rhizoplane of sugar, isolated Trichoderma harzianum only from rhizosphere.

Pelczar (1993) and Martin (1997) also reported that the microorganisms in rhizosphere proliferate better than anywhere else as they obtain their nutrition from roots exudates, plant mucigel and root lysates.

The native population in soil is poor which is insufficient for required by Biological Nitrogen Fixation (BNF) but the population of Azotobacter and Azospirillum in rhizosphere of wheat was 8-10 fold more when soil was ammended with farm yard manure (FYM) or vermicompost (Suthar, 2009).

\section{Beneficiary Microorganisms Nitrogen Fixers}

Nitrogen $(\mathrm{N})$ is a key element responsible for enhancing the crop production. But the economic and environmental cause of the heavy use of chemical $\mathrm{N}$ fertilizers in agriculture are a global concern. The $\mathrm{N}$ fertilizer efficiency is very low so there is need to develop the environment friendly alternative to $\mathrm{N}$ fertilizers keeping in view the aspect of sustainable agriculture and also of maintaining high yield to feed the ever increasing population. Biological fixation of atmospheric Nitrogen can be estimated at about 175 millions metric tons per year or about $70 \%$ of all $\mathrm{N}$ fixed on the earth per year. Biological Nitrogen Fixation (BNF) accounts for $65 \%$ of $\mathrm{N}$ currently utilized in agriculture and of increasingly importance in future crop productivity, especially for sustainable systems and is naturally available subsidy for crop productivity. Besides the obvious scientific interest of nitrogen fixation as a fundamental biochemical reaction and in agriculture, it is of a great ecological importance too since it is the most important source of metabolizable nitrogen needed by all the living organisms. In the process of nitrogen fixation, the enzyme nitrogenase plays an important role. The molecular nitrogen binds to MoFe protein, whereas the $\mathrm{Fe}$ protein, serves specific function of reducing $\mathrm{Fe}$ protein. During the catalytic activity of Nitrogenase, proton and molecular Nitrogen compete for electrons. Therefore, in an environment consisting of Nitrogen $\left(\mathrm{N}_{2}\right)$, Hydrogen $\left(\mathrm{H}_{2}\right)$ production takes place simultaneously when nitrogen is reduced to ammonia

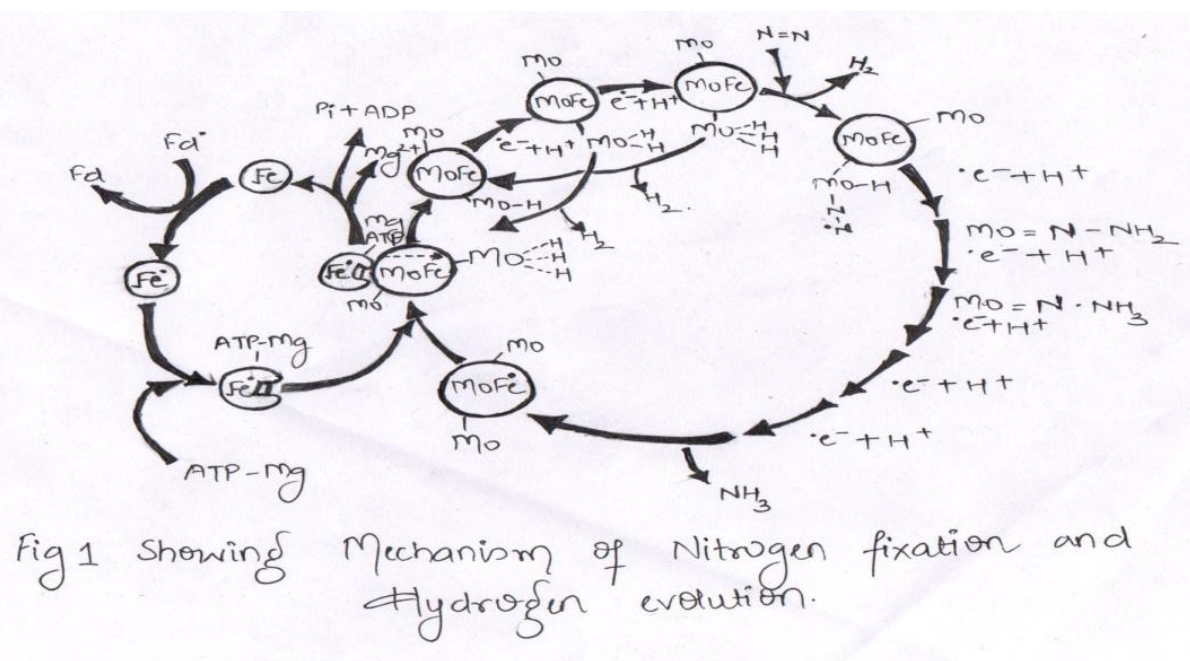


BNF is an energy intensive enzymatic process, consuming ATP upto 42 molecules per molecule of $\mathrm{N}_{2}$ fixed (Brien and Maier, 1989). The absence of any undetectable $\mathrm{N}$ fixation, together with the smaller nodule biomass of tree grown in urea amended soils, is most likely a result available $\mathrm{N}$ in the soil inhibiting $\mathrm{N}$ fixation and nodulation. The effect has been well document for Alnus species (Wall et al, 2000).Quantifying N fixation is, however, very difficult particularly in woody species (Sprent, 2001).

Boring et al (1988) review of research on nitrogen inputs in non-agricultural, terrestrial ecosystems suggested that nitrogen fixation is important in diverse forest ecosystems. Rates of both symbiotic and asymbiotic Nitrogen fixation are greatest during early successional stages of forest development, when they have a major impact on ecosystem productivity. Asymbiotic nitrogen fixation in forest soils may be associated with periodic anaerobiosis or with locally available energy sources.

There are a number of nitrogen fixing microorganisms in nature, broadly divided into symbiotic, asymbiotic or free living and associative Nitrogen fixers (Ramanan et al, 2016). The nitrogen fixing bacteria play a major role in maintaining pools of $\mathrm{N}$ in agriculture and forest soils. Inspite of factors that limit the efficiency of nitrogen fixers, they are probably of great importance to the nitrogen and carbon economics of forests than suspected. Together with atmospheric deposition, genetically marked nitrogen fixing bacteria play a major role in maintaining pools of $\mathrm{N}$ in forests. Also, high $\mathrm{C} / \mathrm{N}$ ratios in wood debris on the forest floor makes nitrogen fixers critical to litter decomposition by associative fungi.

Gaulke et al (2002) analysed the effects of $\mathrm{N}$ fertilization on the Symbiotic Nitrogen fixing relationship between Alnus rubra (red Alder) and Frankia. Anerobically digested, class B biosolids and Synthetic urea (46\% N) were applied at rate 140,280 and $560 \mathrm{Kg}$ /ha available $\mathrm{N}$ to a well drained, sandy, glacial outwash soil in the Indianola series and observed higher $\mathrm{N}$ demand.

A continued supply of $\mathrm{N}$ through biological $\mathrm{N}_{2}$ fixation is another factor supposed to be involved in maintaining large $\mathrm{N}$ pools in undisturbed forests and rebuilding those after disturbances (Vitousek et al, 2002). The process of Nitrogen fixation is important in balancing $\mathrm{N}$ in many ecosystems and agriculture.

Schortemeyer et al (2002) reported that Nitrogen fixation by Acacia species increases under elevated atmospheric $\mathrm{CO}_{2}$. Thapliyal et al (2009) studied biomass $\mathrm{N}$ fixation and $\mathrm{N}$ assimilation activity in Albizia lebbeck plants. On the basis of relative comparison of different doses of $\mathrm{N}$ and $\mathrm{P}$ on individual plants, it was observed that in most of the treatments with low $\mathrm{N}$ and P doses i.e N40 + P400 showed comparatively higher biomass compared to higher doses.

In terms of the quantity of $\mathrm{N}_{2}$ fixed and in its importance to agricultural systems, the symbiosis between root nodule bacteria (RNB collectively known as Rhizobia) and legumes is most the ecologically and economically important form of BNF. It is estimated to contribute approximately $360 \mathrm{Kg}$ of fixed $\mathrm{N}$ per hectare per year to agricultural systems (Herridge et al, 2008).

Wang et al (2010) studied the effects of $\mathrm{N}$ Fixation ( $\mathrm{N}$ fixing and non $\mathrm{N}$ fixing tree species) on soil properties. The $\mathrm{N}$ fixing forests had $40-50 \%$ higher organic matter and $20-25 \%$ higher total $\mathrm{N}$ concentration in the $0-5 \mathrm{~cm}$ soils than the non-N fixing Forests. Soil organic $\mathrm{N}$ was highest under secondary shrublands.

\section{Azotobacter}

Azotobacter are free living, obligatory, rod shaped Gram negative bacilli. They are having the highest respiratory rate among all the $\mathrm{N}_{2}$ fixers. They are oval or spherical bacteria that form cysts and perform asexual reproduction under favourable conditions. Azotobacter species are found in neutral and alkaline soils. They are polymorphic, possess peritrichous flagella and produce polysaccharides. They are sensitive to acidic conditions, $\mathrm{pH}$ and temperature above $35^{\circ} \mathrm{C}$ and can grow on free Nitrogen medium, thus utilize atmospheric $\mathrm{N}_{2}$ for cell protein synthesis. Cell protein get mineralized in soil after death of Azotobacter and contributes to nitrogen availability to crop plants

Genus Azotobacter belongs to family Azotobacteraceae and subclass Proteobacteria. A.chroococum was first discovered and described in 1901 by the Dutch Microbiologist and Botanist Martinus Beijerinck. Then he reported seven species of Azotobacter viz. A. chroococcum, A. vinelandii, A. beijerinckii, A. paspali, A. armeniacus, A. 
migricans and A. salinestri. Azotobacter has also ability to solubilize phosphates besides fixing $\mathrm{N}_{2}$ in aquaculture systems and vermicompost production, hence, performing a dual function.

Azotobacter species have full range of enzymes needed to perform the nitrogen fixation ferredoxin hydrogenase and nitrogenase. The process of nitrogen fixation, require influx of enzymes along with ATP. The enzymes are highly sensitive in the presence of oxygen (Shank etal, 2005). Azotobacter also synthesizes some of the biologically active substances, including some phytohormones such as auxins (Kukreja et al, 2004). Azotobacter can also biodegrade chlorine containing aromatic compounds such as 2,4,6-trichlorophenol, which was previously used as an insecticide, fungicide and herbicide but later found to have mutagenic and carcinogenic effects ( $\mathrm{Li}$ et al, 1991). Azotobacter promotes nitrogen fixation which increases plant growth. Thus, technology has been developed which emphasizes the production of biofertilizers by using Azotobacter on mass scale by scientists. Production of biofertilizers by using Azotobacter has been suggested as an ecofriendly technology. This organism can be used as plant growth promoter because its inoculation benefits wide variety of crops. As excessive use of chemical fertilizers pollutes soil and hence causes environmental pollution. Thus, there is a need to develop plant growth promoting biofertilizers for enhancement of soil fertility. These biofertilizers increase in seed germination, root and shoot length and hence, improve nitrogen nutrition to the plants. These result in reduction in disease incidence, increase in grain yield and improve post harvest seed quality in terms of germination.

1. Subramoney and Abraham (1962) isolated Azotobacter chroococcum strains from redloamy soils of India.

2. Various scientists described different suggestions for classifying and grouping the genus Azotobacter based on morphological and physiological features (Johnstone, 1974).

3. Direct isolation of Azotobacter from soil has been observed by various means (Mishustin and Shilnikova, 1972). Lumps of soils are spread on $\mathrm{N}$-free agar medium and the plates were incubated at $28^{\circ} \mathrm{C}$. Azotobacter colonies developed on the agar plates after three days of incubation.

4. Line and Loutit (1973) investigated the occurrence of Azotobacter among the groups of heterotrophic microbes. They are aerobic bacteria possessing highest respiratory rates and concentration ranging from $10^{3}$ to $10^{5}$ per gram of soil.

5. Mulder and Brotonegoro (1974) preferred to retain the genetic name of Azotobacter. These authors recognized the different species of Azotobacter viz. A. chroococcum, A. vinelandii, A. beijerinckii, A. paspali, A. macrocytogenes and A. agilis.

6. Vela (1974) reported that the cyst formation in Azotobacter is well documented by morphological, ultrastructural and biochemical studies. Cyst are transformed vegetative cells containing abundant of poly hydroxyl butyric acid granules with a high degree of resistance to dessication.

7. Ocampo et al (1975) reported more number of Azotobacter and Phosphobacteria in Rhizosphere when Lavender was inoculated with both groups of organisms together than when inoculated singly.

8. Kavimandan et al (1978) reported the presence of Azotobacter on the Rhizoplane (root surface) followed by rhizosphere.

9. Kundu and Gaur (1980) reported the combined effects of Azotobacter chroococum and PSM on growth rate of plants. They observed that the synergistic effect of these organisms was more pronounced than they are introduced singly.

10. Sengupta (1990) observed that the isolated Azotobacter species had ability to fixatmospheric $\mathrm{N}_{2}$ in pure culture.

11. De Ley and Park (1996) reported DNA analysis and DNA hybridization tests of different species of Azotobacter, Beijerinckia and Derxia. Based on differences in $\mathrm{G}+\mathrm{C}$ percentage composition between species, they also identified three species of Azotobacter viz. A.chroococcum, A. beijerinckii and A.vinelandii.

12. The plant after treatment with A. chroococcum with Fourteen days of culture resulted in seedling roots. A. chroococcumstrain isolated from sugar beet rhizosphere were also known to produce Gibberellins. Due to the production of Gibberellins, the growth of plant was reported to be highest (Mrkovac and Milic, 2001).

13. A study on an intensive wheat rotation farming system reported that all free-living $\mathrm{N}_{2}$ fixing microorganisms fix approximately 20 Kilograms of Nitrogen per hectare per year to the long term (Vadakattu and Paterson, 2006).

14. Adhatoda vasica plants inoculated with A. chroococcum revealed significantly increased root $\mathrm{N}$ content compared to the control plants (Anantha et al, 2007).

15. Substances like amino acids produced by these Rhizobacteria are involved in many processes that help in plant growth promotion. Biochemical analysis of Chorophyll, N, P, K, and protein content was higher in Azotobacter inoculated plants as compared to non-inoculated control plants (Ojaghloo et al, 2007).

16. An experiment was conducted on Jatropha curcas to test efficacy of beneficial microbes (Azotobacter, Arbuscular Mycorrhizal (AM) fungi) individually or in combination to alleviate the stressful effect of alkaline 
soil. The combination of AM fungi and Azotobacter increased plant height, shoot diameter and shoot dry biomass. (Kumar etal, 2009).

17. Several strains of Azotobacter are capable of producing amino acids when grown in a culture media amended with different carbon and $\mathrm{N}$ sources. (Naseri et al, 2013).

18. Combined application of biofertilizer with $50 \%$ of chemical fertilizers $(\mathrm{N}$ and $\mathrm{P}$ ) has significant effect in plant growth, plant height, number of branches, fresh and dry weight of Safflower in comparison to chemical fertilizers alone. Similarly, application of Azotobacter biophsosphate and organic fertilizers, increase the economic yield of Safflower (Soleimanzadeh and Gooshchi, 2013).

19. The rate of increase in leaf area determines the photosynthetic activity of plant, which leads to better assimilation leading to higher yield. Using Azotobacter spp. potato yield has been increased by 33.3\% and $38.3 \%$. Similarly 20\% yield in increment is recorded in Azotobacter inoculated plants (Estiyar et al, 2014)

\begin{abstract}
Azospirillum
Azospirillum, an associative nitrogen fixer shows association with roots of gramineae. It is considered as the best genus of plant growth-promoting Rhizobacteria. Other diazotrophs found in association with plant roots are $A$. diazotrophicus, Herbaspirillum seropedicae and Azoarus spp. Azospirillum is predominately surface colonising bacteria where as A. diazotrophics, Herbaspirillum seropedicae, A. spp and are endophytic diazotrophs. At present, five species has neen described A. lipoform, A. brasilense, A. amazonens, A. halopraferens and A. irakense. They display a versatile carbon and nitrogen metabolism, which makes them well adapted to establish in competitive environment of the rhizosphere. Ammonium, Nitrate, Nitrite, Amino acids and molecular nitrogen can serve as $\mathrm{N}$ source (Vojinoviv, 1961). In unfavourable conditions such as dessication and nutrient limitation, Azospirillum forms cyst like structures. Under certain environmental conditions, Azospirillum can positively influence plant growth, crop yield and $\mathrm{N}$ content of the plant. This plant stimulatory effect exerted by Azospirillum has been attributed to several mechanisms including BNF and Auxin production. Therefore, other factors, such as production of plant growth promoting substances and increase in rate of mineral uptake by plant roots have taken into the account to explain the plant yield enhancement and could be more important in establishing plant response. Azospirillum can convert atmospheric $\mathrm{N}$ into ammonium under microaerobic conditions at low $\mathrm{N}$ levels, though the action of Nitrogenase protein (MoFe protein, NifDK) which contains a molybdenum - iron cofactor is a site of $\mathrm{N}_{2}$ reduction. The dinitrogen reductase protein $(\mathrm{Fe}$ protein, $\mathrm{NifH})$ transfers electron from an electron donor to the nitrogenase protein. Thus, they are able to exert beneficial effects on plant growth and yield of many agronomic crops under a variety of environmental and soil conditions. The positive effects of Azospirillum are mainly derived from morphological and physiological changes of the inoculated plant roots, which leads to an enhancement of water and mineral uptake. Root colonization by Azospirillum takes place mainly in root elongation zone. Inoculation increases the density and the length of root hairs, as well as appearance and elongation of lateral roots, thus increasing the root surface area. Secretion of plant growth promoting substances such as Auxins, Gibberllins and Cytokinins by the bacteria are the most noted cause of the beneficial effects in the plant root system. Therefore, Azospirillum organism is the most beneficial organism which boosts yield and improves overall plant health and shows positive physiological effects, hence resulting in reduction of the application of commercial fertilizers. Azospirillum application to corn and sorghum could reduce the amount of commercial fertilizer needed to grow abundant crop.
\end{abstract}

Tarrand et al (1978) proposed Azospirillum as the genus to differentiate diazotrophic spirilla from others and distinguished two species of A. brasilense and A. lipoferum based on physiological and morphological differences between various strains on DNA homology experiments (Falk et al, 1986). Later seven more species were also described.

Tyer et al (1979) and Dorbereiner et al (1980) reported that Azospirillum is widely distributed in the rhizosphere of several tropical grasses. The Azospirillum has been isolated from the roots of numerous wild and cultivated grasses, cereals, legumes and tropical, subtropical and temperate soils worldwide. Isolated Azospirillum and related diazotrophic bacteria were isolated from the samples of roots, stems and fruits of banana and pineapple (Weber et al, 1999). Azospirilla are microaerophilic often associated with roots of cereals and grasses.

Azospirillum population was reported from $10^{4}$ to $10^{6}$ per gram of soil (Magalhaes et al, 1981).

Azospirillum was mixed along with other microbes viz. Rhizobium and Mycorrhizal which have proven various the best effects on plants (Gallo and Fabri, 1991). 
Kolb and Martin (1985) described the isolation and selection of indigenous Azopirillum from wheat roots. Indole Acetic Acid (IAA) of superior strains affected wheat roots. IAA produced by bacteria can promote plant growth by stimulating root formation. Native Azospirillum spp. isolated from Iranian soils has been evaluated. The roots of wheat seedlings responded positively to the several bacterial inoculations and resulted in increase in root length, dry weight and by lateral root hairs.

Azospirillum amazonense (Falk et al, 1985) isolated from many grasses in Amazonian area of Brazil, the salt tolerant species. A. halopraeferans associated exclusively with roots of gram. A pectinolytic species A. irakense was found in association with rice roots (Khammas et al, 1989).

Rao and Venkateswaralu (1985) reported that the most probable number of Azospirillum varied in root zone of pearl millet and was maximum in the rhizosphere as compared to the rhizoplane and inside roots. Further, its population was found to be maximum in laterite soil and minimum in extremely acid sulphate saline soil.

Hartmann et al (1988) reported the influence of amino acids on $\mathrm{N}$ fixation ability and growth of Azospirillum species. The utilization of amino acids for growth and their effects on Nitrogen fixation differ greatly among of several strains of each species of Azospirillum. The variation in utilization of various amino acids by Azospirillum spp may be important for their establishment in rhizosphere and for their associative Nitrogen fixation with plants. Heulin et al, (1989) reported that in association with the rice, A. lipoferum $\mathrm{N}-4$ contributed about $66 \%$ of the total $\mathrm{N}$ in plants as was demonstrated with ${ }^{15} \mathrm{~N}$ isotope studies.

Gaur and Alagawadi (1989) studied the interaction between Azospirillum brasilense and PSB viz. Pseudomonas striata and Bacillus polymyxa and observed a significant increase in root Nitrogenase activity and yield level of Sorghum due to combined inoculation over single.

Several reports on the agricultural, environmental and physiological aspects of Azospirillum interactions with plants were published in 1990 and 1997 (Bashan and Levanony, 1990; Bashan and Holguin, 1997). Commercial field application, critical analysis of particular sub-field and genetic aspects of plant growth and hence resulting genetic, biochemical and ecological studies have marked Azospirillum as one of the best characterized genera among associative plant growth promoting rhizobacteria.

Attachment of A. brasilense to wheat (Michiels et al, 1990) and maize roots (Jofre et al, 1996) was found to occur stepwise. Firstly, bacteria adsorbed rapidly on the root surface. In this step a protein cell surface component was used for adsorption. In second step the adsorption was mediated by surface polysaccharides or lipopolysaccharides. In such cases, they established in the intercellular spaces between epidermis and the cortex (Dobereiner, 1983) and even in the vascular system.

Alagawadi and Gaur (1992) conducted a field trial in medium black soil under rainfed conditions to study the effect of combined inoculation of Azospirillum brasilense and Pseudomonas striata or Bacillus polymyxa with or without fertilizer N and Rock Phosphate on the yield and nutrient uptake of Sorghum. A significant increase in grain, dry matter, $\mathrm{N}$ and $\mathrm{P}$ uptake of Sorghum due to combined inoculation was reported.

Greenhouse and field trails have been conducted in many places with different crops which revealed that BNF by root associated Azospirillum contributed significant amounts of Nitrogen to the plants thereby saving inorganic nitrogenous fertilizers. Azospirillum inoculation benefits increases yield of crops by improving root development, mineral uptake and water plant relationship (Okon, 1985). The Azospirillum inoculation resulted in increase in total yield of field grown plants and it generally ranged from 10-30\%. The responses varied with crops, cultivators, location, seasons, agronomic practices, bacterial strains, level of soil fertility and interaction with native microflora. Significant yield increase was observed in tomato plants with the inoculation of Azopirillum spp (Bashan and Holiquin, 1997). Inoculation of Azospirillum sp. to wetland ice under acidic condition improved shoot growth, straw yield and N uptake (Govindan and Bagyaraj, 1995). Moreover, Salomone and Dobereiner (1996) observed significant increase in grain yield of maize on inoculation with Azospirillum spp.

Kucey et al (1993) indicated that upto $18 \%$ of the plant Nitrogen was derived from Nitrogen fixation. All wild types Azospirillum strains were found to fix Nitrogen efficiently either as free living or in association with plants. 
Omay et al (1993) reported the effect of Azospirillum sp. inoculation in wheat, barley and oat seeds in greenhouse experiments. The wheat yield significantly increased after the inoculation of Azospirillum along with Nitrogen fertilizers. For barley, the presence of the inoculants substituted $20 \%$ of the recommended N fertilizer. For oats the inoculation with Azospirillum did not provide significant increase in grain yields.

Hemavathi (1997) observed improved plant growth and flower yield of Chrysanthemum on inoculation with Azospirillum sp.over the uninoculated control.

Rai and Caur (1998) studied the single and double effect of Azotobacter and Azospirillum on wheat growth and yieldand reported the positive results.Double interaction of Azotobacter and Azospirillum had positive effect on grain yield, biological yield and harvest index in various genotypes.

Alagwadi and Krishnaraj (1998) studied the effect of two Azospirillum strains viz. ACD-15 and ACD-20 on growth and yield of Sorghum under field conditions. They observed significant increase in grain yield of Sorghum over the control.

Cassan et al (2001) reported A. brasilense strain cd and A. lipoferum strain USA 5b promoted shealth elongation of two single gene GA deficient drawf rice mutants, when the inoculated seedlings were supplied with $\mathrm{GA}_{20^{-}} \mathrm{glycosyl}$ ether.

Dobbelaere et al (2001) observed a significant increase in dry weight due to inoculation of wheat plants with A.brasilense SP-245 and A. irakense $\mathrm{KBC} 1$ in Belgium.

A dobereinerae was found in association with roots of the graminaceous plant Miscanthus (Eckert et al, 2001). A. oryzae was isolated from roots of rice plant Oryzaesativa (Xie and Yokota, 2005) and A. melinis from tropical molasses grass (Peng et al, 2006). However, most common species are either A. brasilense or A. lipoferum.

Baby et al (2002) reported the inoculation of bioformulation or liquid near rhizosphere of tea seedling significantly increased its growth.

Polyanskaya et al (2002) studied the growth promoting effect of two strains of Beijerinckia mobilis and Clostridium sp. isolated from pea rhizosphere on some agricultural crops and reported that application of B. mobilis and Clostridium sp. cultures in combination with mineral fertilizers increased the crop yield by 1.5 to 2.5 times. Significant growth and yield increase was observed in rice plants due to the inoculation of Azospirillum lipoferum.

Gadagi Ravi et al (2003) reported the effect of Azospirillum amazonense inoculation on growth, yield and Nitrogen fixation of rice. Bacteria of genus Azospirillum stimulated plant growth directly either by synthesizing phytohormones or by promoting nutrition by the process of BNF. The nitrogenaseactivity also was variable and only $9 \%$ of isolates showed high nitrogenase activity and the majority (54\%) exhibited a low potential.

Gadagi et al (2004) examined the effect of Azospirillum inoculation on yield response of the Gaillardia pulchella. Azospirillum strain OAD-2 inoculationsignificantly increased plant height, number of leaves per plant, branches per plant and total dry mass accumulation in G. pulchella than uninoculated control. Azospirillum strains OAD-2 and OAD-11 can play an important role in the Nitrogen nutrition in G. pulchella.

Enhanced shoot growth and nitrogen content of whole tomato plant was observed by Meunchang et al (2006) in soil amended with sugar by product compost inoculated with Nitrogen fixing bacteria viz Azotobacter vinelandii, Bejerinickia derxii and Azospirillum lipoferum either alone or in combination with $\mathrm{N}$ fertilizer and it increased the plant height, dry weight and total $\mathrm{N}$ content of shoot and root.

Saikia et al (2007) described that dinitrogen fixation activity of $A$. brasilense in maize. The increased nitrogenase activity was noticed in plants treated with Azospirillum.

Kandil et al (2011) studied the effects of inoculation with Azotobacter sp. and Azospirillum sp. on wheat and observed that inoculated wheat plants gave higher plant height, spike per unit of area, grains per spike, grain weight, biological yield, yield and straw yield compared to un-inoculated control. 
Among the different inoculations, combined application of Azotobacter spp. and Azospirillum spp. was found to be the most efficient and resulted in maximum values of plant growth parameter, yield attributing characterstic, grain yield (1.23Mg/ha) soil microbial biomass carbon (SMBC) and dehydrogenase activities at all the growth stages of common buckwheat (Singh et al, 2015). According to Das and Sha (2007) combined inoculation of Azotobacter, Azospirillum along with other diazotrophs increased grain and straw yield by rice 4.5 and $8.5 \mathrm{~kg} / \mathrm{ha}$, respectively.

\section{Pseudomonas}

Pseudomonas is Gram negative bacteria belonging to family Pseudomonaceae. It is aerobic bacillus measuring upto 0.5 to $0.8 \mu \mathrm{m}$. Pseudomonas is a bacterium which is saprophytic in nature. Pseudomonas is rod shaped, slender organism, motile by polar flagella out sometimes more than two flagella may be present. Members of genus Pseudomonas occupy a dominant position in the biosphere in terms of number of species in a given habitat. Pseudomonas species are found in large number in all major natural environments terrestrial, freshwater, marine and in associations with various plants and animals (Clark and Slater, 1986). Members of this genus are described in Bergey's Manual of Systematic Bacteriology (1984) as being straight and slightly curved rods. Pseudomonas species are strictly aerobic and chemoorganotrophic. The optimum growth temperature for the most strains is $28^{\circ} \mathrm{C}$ but are capable of growing at temperature in the range of $4-43^{\circ} \mathrm{C}$. Pseudomonas produces large, opaque, flat colonies with irregularly margins and distinctively fruity odour colonies. The colors of growth will depend upon the type of pigments produced by organism. The isolates from water and soil produces small round colonies. The isolates from clinical specimens like respiratory, urine etc. may produce mucoid colonies. The bacteria which form mucoid colonies are more virulent as compared to others. The pigments produced by Pseudomonas is Pyoverdis (greenish yellow, Fluorescent pigment), the blue pigment pyocyanin (bluish green), Pyrubin (red) and Pyomelanin (brown).

Pigments can be soluble in water and freely diffusible into culture media or they can remain associated with the cells. The best known soluble pigments are the fluorescent pigments of some members of RNA group 1. The fluorescent Pseudomonads include P. aeruginosa, $P$. fluorescens and P. putida. These pigments act as siderophores, strong iron chelators and allow growth in media having having a low iron content. Another important soluble pigment is pyocyanin, a phenazine derivative characterstics of $P$. aeruginos. Pseudomonas species are subdivided on the basis of RNA homology. There are five RNA groups. The best known species of the genus are included in Group 1. P. fluorescens and P. putida are well known members of RNA homology 1 . Both are complex species and can be subdivided into a number of biovars or biotypes (Palleroni, 1986). One of the most striking properties of members of this genus is their remarkable nutritional versatility. Organic compounds readily used by Pseudomonas species include alcohols, aliphatic, amines, acids, amides, aromatic compounds, carbohydrates and hydrocarbons. The ability to utilize a wide range of compounds makes Pseudomonas species an important components of activated sludge particularly that treating wastewater derived from the chemical industry. Pseudomonas are readily isolated that can use aromatic compounds as their major source of energy for growth as these compounds are widely distributed in natural environments. Many of the aromatics compounds found in the environment are derived the combustion of oil and coal (Dagley, 1986).

The application of selected and adapted Pseudomonas species to polluted soils and water may help to improve the removal of pollutants from the environment.

Enhanced plant growth by bacteria has been reported by various researchers throughout the world (Cooper, 1959). With better understanding of rhizosphere and different mechanisms of action of Plant Growth Promoting Rhizobacteria (PGPR), practical aspects of inoculant formulation and delivery increases. This may lead to development of newer (PGPR) products. PGPR are a group of bacteria that are helpful in enhancement of plant growth promoting substances and they present an environmentally sustainable approach for enhancing crop production.

Libbert and Risch (1969) reported that among the 109 strains of the genera Achromobacter, Alcaligenes, Bacillus, Flavobacterium, Pseudomonas etc. only 58 strains produced IAA from Tryptophan. Brown (1972) isolated microorganisms in rhizophere, rhizoplane and non-rhizosphere soil of wheat plants and assayed the ability of these microbes to produce IAA in culture medium ammended with tryptophan, Many reports indicated the IAA production by Phyllosphere and Mycorhizosphere microorganisms. 
The rhizosphere occurrence and activities of Pseudomonas fluorescens, as PGPR, have been considered as an important component of sustainable agriculture due to their plant growth promoting ability as well as their biocontrol potential against phytopathogens. The ubiquitous occurrence and activities of Pseudomonas fluorescens in the rhizosphere of many crop plants have already been reported (Lindow and Brandl, 2003).

Dowling and O' Gara (1994) reported that many strains of Pseudomonas producing (IAA) stimulated the plant root elongation by stimulating the growth of root hairs. A diverse set of bacterial genera and species has been found to synthesis IAA, including soil, epiphytic and tissue colonizing bacteria. Moreover, the IAA biosynthetic pathways and gene involved in their regulation and expression are too many (Costacurta and Varderleyden, 1995).

There is evidence that the compost naturally contain many species of PGPR (Alvarez et al, 1995), as well as plant growth hormones such as auxin (Canelles et al, 2002). Owing to the complex microbial ecology of composts, the presence of many strains of PGPR is not necessarily an indicator that the compost as a whole will be suppressive to plant diseases.

The interactions between PGPR and Nitrogen fixers may be synergistic or antagonistic. The beneficial effects of these interactions can be exploited for increasing the biological N fixation and crop yield (Dubey, 1996). Due to harmful effects of artificial fertilizers on the environment and their high cost, there has been increase in the use of beneficial soil microorganisms such as PGPRs for the agriculture all around the world. PGPR are considered as efficient biofertilizers for sustainable agriculture therefore, enhancing output of crops.

The occurrence and activities Pseudomonas fluorescens in the rhizosphere have already been reported in tobacco (Troxhler et al, 1998) and tomato (Yan et al, 2002). They showed that Pseudomonas spp combined with optimum concentration of Nitrogenous fertilizers was able to provide a substantial crop yield. Pseudomonas, as PGPR, are believed to increase the supply of primary nutrients availability to the host plant (Wu et al, 2005), promoting the synthesis of antibiotics, enzymes and fungicidal compounds.

Carbonaro et al (2002) studied that one of the physiological changes induced in plants by PGPR is an increased production of antioxidants.

Along with the hormone-producing and nutrient mineralizing strains of PGPR, many PGPR have been shown to prevent a wide variety of plant diseases in greenhouse and field trials. Many practitioners who are committed to limiting chemical pesticides use are interested in using PGPR and other bio-control agents as alternatives. Even with the great potential documented in the scientific literature, very few plant diseases suppressing PGPR are available commercially to growers (Nelson, 2004).

Microorganisms isolated from leaf surface of potato, tomato, rice, sugarcane, jute wheat and mustard produced IAA in the culture medium amended with tryptophan (Banerjee and Chandra, 1978). The importance of IAA secreted by PGPR, in the stimulation of plant growth is less clear. Earlier observation with Azotobacter, Azospirillum and some strains of Pseudomonas putida indicated the production of IAA in culture medium when ammended with tryptophan. The size of the bacterial population might determine the degree of plant growth promotion and reflected the level of bacterially produced IAA available to plant (Okon and Gonazlez, 1994).

Brown (1974) reported the phytohormones production by PGPR. The most common and characterized is Indole-3acetic acid (IAA) which is known to stimulate the cell elongation and cell division of plant roots. Since plants as well as PGPR could synthesis auxin, it is important to assess the consequences of treating a plant in response to PGPR inoculation and the auxin synthesized by the PGPR itself.

Sridhar (1996) isolated and characterized ten Pseudomonas fluorescens producing $3.8 \mu \mathrm{g} \mathrm{mL}^{-1} \mathrm{and}_{0.9} \mu_{\mathrm{g} \mathrm{mL}}^{-1}$ of IAA in culture medium during the presence and absence of tryptophan, respectively.

Pseudomonas putida strain GR 12-2 was able to produce IAA, in the presence of tryptophan analog viz. 5 fluorotryptophan and other produced IAA mutant range 2.01 to $8.28 \mu \mathrm{g} \mathrm{mL} \mathrm{mL}^{-1}$ (Xie et al, 1996). The IAA biosynthesis by Pseudomonas fluorescens revealed the conversion of L-tryptophan into Indole-3-acetic acid via Indole-3-pyurvic acid. 
Afzal et al (2005) reported increased yield and $\mathrm{P}$ uptake of wheat plants due to inoculation of mixture of Pseudomonas and Bacillus sp. Frietas and Germida (1990) isolated Phosphate solubilizing microorganisms such as P. aerugonisa, $P$. cepacia, $P$. fluorescene and $P$. putida from rhizosphere of wheat and Bacillus licheniformis, B. mycoides, B. megaterium from the rhizosphere of paddy (Watanabe and Hayano, 1993).

Beom et al (2006) reported the Pseudomonas fluorescens $89 \mathrm{~b} 61$ and Bacillus pumilus SE34, secreted higher levels of Indole-3-acetic acid (IAA) in tryptophan amended medium at stationary level phase.

Khakipour et al (2008) reported that the Pseudomonas fluorescens and Pseudomonasputida are the most important kinds of PGPR for the production of IAA $\left(31.6 \mathrm{mg} \mathrm{L}^{-1}\right.$ and $24.08 \mathrm{mg} \mathrm{L}^{-1}$, respectively) which could stimulate the plant growth promotion and yield of many crop species.

Several Pseudomonas strains produced siderophores that increased plant growth by increasing iron solubility in the rhizosphere of plants. Siderophores are chelating agents that possess high affinity for absorption of Iron. About 30 PGPR strains belonging to Fluorescent Pseudomonas with PGPR activities were isolated from the rhizosphere of rice and characterized by PCR-RAPD analysis (Reddy and Reddy, 2009).

Khare and Arora (2010) reported the production of Indole-3-acetic acid by Rhizobacteria which resulted in plant growth promotion, especially root initiation and elongation. The mutant isolate TO3, produced IAA and it exhibited the biocontrol and plant growth promoting activities too.

Jayasudha et al (2010) quantitatively evaluated for IAA producing ability of forty fluorescent Pseudomonas in the presence $\left(\operatorname{trypt}^{+}\right)$or absence (trypt ${ }^{-}$) of tryptophan and growth promotion in groundnut was analysed in response to seed treatment. They revealed that IAA producers of the fluorescent Pseudomonas group showed significant plant growth promotion when compared to control but plant growth was not greatly influenced by those organisms which produced high amounts of IAA. Antagonistic Pseudomonas sp. able to release moderate or even low amount of IAA which may be better growth promoters.

Mahmoud et al (2010) proposed that the inoculation of IAA producing Fluorescent Pseudomonas strain significantly increases the growth, yield and nutrient uptake of rice plant, when compared to uninoculated control.

Ramezanpour et al (2011) reported the high level PGPR activities of Flourescent Pseudomonas, such as IAA biosynthesis, Phosphate solubilization and Siderophores production for the enhancement of plant growth stimulation and yield of rice plant. Further, the RFLP of 16S rRNA assay confirmed that these were genetically similar and mainly belonged to Pseudomonas fluorescens,Pseudomonas putida and Pseudomonas aeruginosa, respectively.

Deshwal et al (2013) isolated 140 PGPR strains of Pseudomonas from Potatoes rhizosphere at Dehradun valley, India. Malleswari and Bagyanarayana (2013) isolated 219 strains from the rhizosphere soil samples of different medicinal and aromatic plants viz. Artemisia vulgaris, Acorus calamus, Aloe vera, Tagetes erecta, Mimosa pudica Mentha spiciata, Withania somnifera, Ocimum sanctum and Andrographis paniculata.

Egamberdieva (2010) analyzed the plant growth promoting bacteria for their growth- stimulating effects on two wheat cultivators carried out in pot experiments using calcareous soil. Bacterial strains Pseudomonas sp. and Pseudomonas fluorescens colonized the rhizosphere of both wheat cultivars and significantly stimulated the shoot, root length and dry weight of wheat. About 144 rhizospheric bacteria were isolated from cucumber and screened for their bio-control activities against Phytophthora drechsleri, casual agent of cucumber root by Maleki et al (2010). Based on dual culture assays, eight isolates were selected for root colonization and PGPR traits in greenhouse studies. Isolate CV6 showed the highest root colonization and significant plant growth promotion under in vitro conditions.

\section{Factors affecting Nitrogen Fixation}

Fluctuations in $\mathrm{pH}$, nutrient availability, temperature, water status and other factors, greatly influence the growth, survival and metabolic activities of $\mathrm{N}$ fixing bacteria. The subsequent inhibition of nitrogenase would result in $\mathrm{O}_{2}$ accumulation in the infected zones, including decrease in nodule permeability. In some instances, environmental pollution perturbation independently influence the nodulation and N fixation process. (Vitousek et al, 2002). Stress factors viz. water stress, salt stress etc. simultaneously affect the phenomenon of Nitrogen fixation. 
Maathuis (2009) reported that low $\mathrm{N}$ availability can fluctuate greatly in both space and time due to factors such as precipitation, wind, time, soil type and $\mathrm{pH}$. Therefore, the preferred form in which $\mathrm{N}$ is taken up depends on plant adaptation to soil conditions. Generally, plant adapted at low $\mathrm{pH}$ and reduced aerobic soils (found in Arctic Tundra) generally take up ammonium or amino acids, whereas, plants adapted to higher $\mathrm{pH}$ and more aerobic soils prefer nitrate.

\section{Soil water content and stress}

It is the one of the most important factor influencing the microbial population and their activity in soil. Water (soil moisture) is useful for microorganisms in two ways. It serves as a source of nutrients and supplies hydrogen and oxygen to the organisms and it acts as a solvent to the microorganisms. Microbial activity and population proliferate best in the moisture range of $20 \%$ to $60 \%$. Under excess moisture conditions/ water logged conditions due to lack of soil aeration (oxygen) anaerobic microflora becomes active and the aerobes get suppressed, while the absence of adequate moisture in soil, some of the microbes die out due to tissue dehydration and others change their forms into resting stages spores or cysts and tide over adverse conditions. Therefore, optimum soil moisture range (20-60\%) must be there for the better population and the activity of microbes in soil. Thus resulting, Soil water influences the growth of soil microorganisms through processes of diffusion, mass flow and nutrient concentration. Soil aggregates having smaller internal pore spaces are more favourable environments for the growth of $\mathrm{N}_{2}$ fixers and most soil microbes (Turco and Sadowsky, 1995). Soil water content also directly influences the growth of rhizosphere microorganisms by decreasing water activity below critical tolerance limits, alternating plant growth, root architecture and exudations.

\section{Seasonality and Temperature effects}

Temperature has a marked influence on survival and persistence of $\mathrm{N}_{2}$ fixers strains in soils either by biological, physical and chemical processes on microbes, microbial activity and on soil population. Though the microorganisms can tolerate extreme temperature ( $\mathrm{such}$ as $-60^{\circ}$ to $+60^{\circ}$ ) conditions but the optimum temperature ranges at which the soil microorganisms can grow and function actively. Depending upon the temperature range at which microorganisms can grow and function are classified into, Psychrophiles (growing at low temperature below $10^{\circ} \mathrm{C}$ ). Mesophiles (growing well in the temperature range of $20^{\circ} \mathrm{C}$ to $45^{\circ} \mathrm{C}$ ) and Themophiles (tolerate temperature above $45^{\circ} \mathrm{C}$ ) and Optimum $\left(45^{\circ} \mathrm{C}-60^{\circ} \mathrm{C}\right)$. Most of the soil microorganisms are mesophilic $\left(25-40^{\circ} \mathrm{C}\right)$ and optimum temperature for the most mesophiles is $37^{\circ} \mathrm{C}$. True psychrophiles are almost absent in soil though present in the soil behaves like mesophiles. True mesophiles are almost abundant in decaying manure and compost heaps where high temperature prevails. In winter season, most of the microbial activity reduces but, In spring, the microbes increase in number as well as in activity. In general population and activities of soils of microorganisms are the highest in spring and lowest in winter season.

The N-fixing activity of Diazotrophs varies over the year. High root temperature has also been shown to influence infection, Nitrogen fixation ability, legume growth (Hungria and Franco, 1993) and has a strong influence on specific strain and cultivar interactions (Arayankoon et al, 1990).

Capone (1998) saw a possible reason for the tendency in the increased activity in warmer temperature in summer time. In exploration of peat bogs (Kravchenko, 2003), it was possible to identify nitrogenase activity in a temperature range from $5^{\circ}$ to $45^{\circ} \mathrm{C}$. But the optimum temperature lies in a smaller range of $25^{\circ}$ to $35^{\circ} \mathrm{C}$. A study on temperature effects of free living heterotrophic diazotrophs presented the similar results. In marshes, the maximum microbial activity was found in July and the N-fixing rate reached its low point in the February (Taylor et al, 2003). Aranjuelo et al (2007) evaluated the effect of elevated temperature and water availability on carbondioxide exchange and Nitrogen fixation of nodulated Alfalfa plants.

\section{Soil pH Stress}

The influence of soil $\mathrm{pH}$ on the nodulation process has been extensively examined in part due to the world's large number of acid soils. Low soil $\mathrm{pH}$ is generally accepted as an indicator of conditions under which some other soil properties may limit crop growth rather than as a primary cause of poor growth. In addition to the direct effects on soil acidity, factors on plants, growth and legumes may be reduced indirectly through depression of nodulation and nitrogen fixation. In this regard, Diazotrophs may have different tolerances to soil acidity factors than host plant.

Brockwell et al (1991) reported a nearly $10^{-3}$ decrease in the number of Sinorhizobium eliloti in soils with a $\mathrm{pH}<6$ compared to those with $\mathrm{pH}>7$. The organisms fixing $\mathrm{N}_{2}$ do not or rarely survive at $\mathrm{pH}$ values 4.5 to 5.0. Although 
the micro-symbiont appears to be more $\mathrm{pH}$ sensitive than the host partner, acidity also influences both the growth of the legume plant and the infection process. Interestingly, nodulated legumes appear more sensitive to metal toxicity by $\mathrm{Mn}$ and $\mathrm{Al}$ than to their $\mathrm{N}$-fed control counterparts.

Worldwide, more than $1.5 \mathrm{~g} / \mathrm{ha}$ of acid soils limit agriculture production (Graham et al, 2000) and as well as $25 \%$ of the earth's croplands are impacted by problems associated with soil acidity.

\section{Soil nutrients and Time effects}

Soil nutrients status has a tremendous influence on the $\mathrm{N}_{2}$ fixation as well as independent growth and survival of both partners. Fixation, therefore, also tends to decrease with legume age, mainly because of the concomitant increase in soil N. A negative exponential relationship was observed between Nitrogen fertilizer rate and Nitrogen fixation when $\mathrm{N}$ was applied to 0 to $20 \mathrm{~cm}$ of the top soil or to the soil surface. The difference in the relationship arises from a variation in $\mathrm{N}$ supply derive from indigenous sources (net soil $\mathrm{N}$ minerialization, irrigation, atmospheric deposition) and possibly other factors affecting growth and Nitrogen fixation. In some cases, it is noted that nutrient stresses are indirectly caused by changes in soil matric potential or acidity which limits the nutrient bioavailability. Acid and water stress causes alternation in root growth, which can indirectly affect Nitrogen fixation this effect is thought to be mediated by abscisic acid. In young soils nutrient availability is strongly prohibit and pioneer organisms take advantage of this circumstances. Pioneer organisms can deal with an environment devoid of life and nutrient poor. At the beginning of, succession that is the observed process of change in the species structure of an ecological community over time, many pioneer are found. These specific clades containing Pioneer organism, modify their environment and establish conditions under which more common and advanced organisms can colonize. Diazotrophs also belong to the pioneer group (Rastetter et al, 2001). Since N is limiting in young soils, all organisms which do not require $\mathrm{N}$ from the soil are benefited. These favoured organisms include diazotrophs and organisms which have a symbiotic relation to such bacteria. A major factor determining the structure of diazotrophs is time. Soil ageing process influences the soil N-pool. (Taylor et al, 2003).

\section{Soil fertility}

Fertility level of soil also contributes to the microbial population and their activity in soil. The availability of N, P and $\mathrm{K}$ required for plants as well as microbes in soil determines the fertile level of soil.

\section{Microbial Associations/Interactions}

Microorganisms interact with each other giving rise to anatagonistic or synergistic interactions. The association existing between one organism and another whether of synergistic or antagonistic influences the population and the activity of soil microbes to a great extent. The predatory habits of protozoa and some Mycobacteria which feed on bacteria may suppress or eliminate certain bacteria. On the other hand, the activities of some of the microorganisms are beneficial to each other. For instance, organic acid liberated by fungi, increase in oxygen by the activity of algae, change in soil reaction etc. favors the activities of bacteria or other organisms in soil.

\section{Root exudates}

In the soil where plants are growing, the root exudates also affect the distribution, density and activity of soil microorganisms. Root exudates slough off material of root surfaces, provide an abundant source of energy and nutrient and thus directly or indirectly influence the quality as well as quantity of microorganisms in the rhizosphere region. Root exudates contain sugar, organic acid, amino acids, sterols, vitamins and other growth factor which have the profound effect on soil microbes.

\section{References:-}

1. Afzal, A.; Ashraf, M.; Asad, S.A. and Farooq, M. (2005). Effect of phosphate solubilizing microorganisms of Phosphorus uptake, yield and yield traits of wheat (Triticum aestivum L.) in rain fed area. International Journal of Agriculture and Biology, 7(2):207-209.

2. Agnihotrudu, V. (1953). Soil conditions and root diseases VIII. Rhizosphere microflora of some important crops of South India. Proceedings Indian Academy of Sciences, 37: 1-13.

3. Alagawadi, A.R. and Gaur, A.C. (1992). Inoculation of Azospirillum brasilense and Phosphate solubilizing bacteria on yield of sorghum (Sorghum bicolor (L.) Moech) in dry land. Tropical Agriculture, 69:347-350.

4. Alagawadi, A.R. and Krishnaraj, P.U. (1998). Field performance of two local rhizobacteria isolates in sorghum. $37^{\text {th }}$ Annual conference of association of Microbiologists on India, Mangalore, pp 278. 
5. Alvarez, M.; Gagne, S. and Antoun, H. (1995). Effect of compost on growth promoting rhizosphere. Applied Environmental Microbiology, 61:194-199.

6. Anantha, N.T.; Earanna, N. and Suresh, C.K. (2007). Influence of Azotobacter chroococcum strains on growth and biomass of Adothoda Vasica Nees. Karnataka Journal of Agricultural Science, 20(3):613-615.

7. Arayankoon, T.; Schomberg, H.H. and Weaver, R.W. (1990). Nodulation and Nitrogen fixation of Guar at high root temperature. Plant Soil, 126:209-203.

8. Ashmarin, I.P. and Vorobyov, A.A. (1962). Staticheskiye metody v microbiologicheskih issledovaniyan. (Statistic methods in Microbiology Research). Medgiz Publishers Leningrad (In Russian), pp 75-78.

9. Baber, D.A. and Lynch, J.M. (1977). Microbial growth in rhizosphere. Soil Biology and Biochemistry, 9:305308.

10. Baby, U.I.; Tensingh, B.; Ponmurugan, P. and Premkumar, R. (2002). Effect of Azospirillum on nursery grown tea plants. In: Proceeding the $15^{\text {th }}$ plantation crop system (eds.). Sreedharan, K.; Vinodkumar, P.K.; Jayarama and Chulaki, B.M., pp 369-374.

11. Backer, P.M.; Wand, H.; Weissbrodt, E.; Kuschk, P. and Stottmeister, U. (1997). Distribution of contaminants and the self purifying potential for aromatic compounds in a Carbonization, Wastewater deposit. Chemosphere, 34:731-748.

12. Banerjee, M and Chandra, A.K. (1978). Auxin production potentially of Nitrogen fixers isolated from the phyllosphere of crop plants. Current Science, 7:962-963.

13. Barea, J.M.; Boris, A.F. and Oliveres (1983). Interaction between Azospirillum and Vesicular Arbuscular Mycorrhizal fungi, their effects on growth and nutrition of Maize and Ryegrass. Soil Biology and Biochemistry, 15:705-709.

14. Bashan, Y. and Holguin (1999). Azospirillum plant relationship: Environmental and Physiological advances (1990-1996). Canadian Journal of Microbiology, 43:103-121.

15. Bashan, Y. and Levanony, H. (1990). Current status of Azospirillum inoculation technology. Azospirillum as a challenge for agriculture. Canadian Journal of Microbiology, 35:591-608.

16. Beijerinck, M.W. (1901). Uber Oligonitophile Mikroben, Zentrollattfiir Bacteriologie, Parasitenkunde, Infektions Krankheiten and Hygiene, Abteilung II, 7:561-582.

17. Beom, R.K.; Kwang, Y.Y.; Baik, H.C.; Tae, H.H.; Seon, K. and Myung, C.L. (2006). Production of Indole-3Acetic Acid in the plant beneficial strain Pseudomonas chlororaphis 06 is negatively regulated by the global sensor Kinase Gac S. Current Microbiology, 52:473-476.

18. Bergy, 1984. Bergey's Manual of Systematic Bacteriology. (eds.) Kreg, N.R., Williams and Wilking. Baltimores, MA, USA.

19. Black, C.A. (1965). Methods of Soil Analysis Agron Monograph 9 Part 2. Chemical and Microbiological Properties, pp 1179-1206.

20. Blagodatskaya, E.; Blagodatsky, S.; Dorodnikov, M. and Kuzyakov, Y. (2010). Elevated atmospheric carbondioxide increases microbial growth rates in soil: Results of the carbondioxide enrichment experiments. Global Change Biology, 16:836-848.

21. Boring, L.R.; Swank, W.T.; Waide, J.B. and Henderson, G.S. (1988). Sources, fates and impacts of Nitrogen inputs to terrestrial ecosystems: Review and synthesis. Biogeochemistry, 6:119-159.

22. Brockwell, J.; Pilka and Holiday, R.A. (1991). Soil pH is the major determinant of the numbers of naturally occurring Rhizobium meliloti in non-cultivated soils in New South Wales. AustralianJournal of Agricultural Research, 31:211-219.

23. Brown, M.E. (1972). Plant growth substances produced by microorganisms of soil and rhizoshere. Journal of Applied bacteriology, 43:443-451.

24. Canellas, L.P.; Olivares, F.L.; Okorokova and Facanha, A.R. (2002). Humic acids isolated from earthworm compost enhance root elongation, lateral root and plasma membrane $\mathrm{H}^{+}$- ATPase activity in maize roots. Plant Physiology, 130:1951-1957.

25. Capone, D.G. (1988). In: Blackburnsn, T.H. and Sorensen, J. (eds.), Benthic Nitrogen Fixation Wiley, New York, pp 85-123.

26. Carbonaro, M.; Mattera, M.; Nicoli, S.; Bergamo, P. and Cappelloni (2002). Modulation of antioxidant compounds in organic vs conventional fruit peach (Prunus persica L.) and pear (Pyrus communis L.). Journal of Agriculture and Food Chemistry, 50(19):9-11.

27. Cassan, F.; bottini, R.; Schnider, G. and Pkcoli, P. (2001). Azospirillum brasilense and Azospirillum lipoferum hydrolyze conjugates of $\mathrm{GA}_{20}$ and metabolize the resultant Aglycones to GA, in seedlings of rice dwarf mutants. Plant Physiology, 125(4):2053-2058.

28. Clark, F.E (1949). Soil microorganisms and plant roots. Advanced Agrotechnology, 1:241-288. 
29. Clark, P.H. and Slater, J.H. (1986). Physiology and Ecological Diversity. In: Evolution of enzyme structure and function inPseudomonas (ed. Cardiff, C.F., University of Wales Institute of Science and Technology). United Kingdom, Acadamic Press, 10:71-75.

30. Cooper, R. (1959). Bacterial fertilizers in the sovient union. Soil Fertility, 22:327-333.

31. Costacurta, A. and Vanderleyden, J. (1995). Synthesis of phytohormones by plant associated bacteria. Critical Review of Microbiology, 21:1-18.

32. Dagley, S. (1986). Biochemistry of aromatic hydrocarbon degradation in Pseudomonas. In the Bacteria- A Treatise on the structure and function. The biology of Pseudomonas (ed) Sokatch, J.R. Acadamic Press. Volume 10.

33. Das, A.C. and Saha, D. (2007). Effects of diazotrophs on mineralization of organic Nitrogen in the rhizosphere soils of rice (Oryza sativa L.). Journal of Crop Weed, 3:69-74.

34. De Frietas, J.R. and Germida, J.J. (1990). Plant growth promoting rhizobacteria for winter wheat (Triticum aestivum). Canadian Journal of Microbiology, 36(4):265-272.

35. De Ley, J. and Park, I.W. (1966). Molecular biological taxonomy of some free living Nitrogen fixing bacteria. Antonie van Leeuwenhoek, 32:6

36. Del Gallo, M. and Fabri, P. (1991). Effect on soil organic matter on chickpea inoculated with Azospirillum brasilense and Rhizobium leguminosarumbv. ciceri. Plant and Soil, 137:171-175.

37. Deshwal, V.K.; Singh, S.B.; Chubey, A. and Kumar, P. (2013). Isolation and characterization of Pseudomonas strains from potato rhizosphere at Dehradun valley, India. International Journal of Basic and Applied Sciences, 2(2):53-55.

38. Dobbelaere, S.; Croonenborghs, A.; Thys, A.; Ptacek, D.; Vanderleyden, J.; Dutto, P; Labandera-Gonzalez, C.; Caballero-Mellado, J.; Aguirre, J.K.; Kapulnik, Y.; Brener, S.; Burdman, S.; Kadouri, D.; Sarig, S. and Okon, Y. (2001). Responses of agronomically important crops to inoculation with Azospirillum. Australian Journal of Plant Physiology, 28:871-879.

39. Dobereiner, J. (1980). Forage grasses and grain crops. In: Methods for evaluating biological Nitrogen fixation (ed.) Bergenson, F., John Wiley and Sons, Limited, pp 535-552.

40. Dobereiner, J. (1983). Ten years of Azospirillum. In: Experientia supplementumAzospirillum II (ed.) Klingmuller, W. and Basel, B.V. 48:9-22.

41. Dobereiner, J.; Marriel, J.E. and Nery, M. (1996). Ecological distribution of spirillum Beijerinck. Canadian Journal of Microbiology, 22:1464-1473.

42. Dowling, D.N. and O' Gara, F. (1994). Metabolites of Pseudomonas involved in the biocontrol of plant disease. Trends Biotechnology, 12:133-144.

43. Dubey, S.K. (1996). Combined effect of Bradyrhizosphere japonicum and Phosphate solubilizing Pseudomonas striata on nodulation, yield attributes and yield of rain fed soyabean (Glycine wax) under different sources of Phosphorus in vertisols. Indian Journal of Microbiology, 33:61-65.

44. Eckert, B.; Weber, O.B.; Kirchhof, G.; Halbritter, A. Stoffles, M. and Hartmann, A. (2001). Azospirillum doebereinerae sp. Nov. a nitrogen fixing bacteria associated with the $\mathrm{C}_{4}$ grass Miscanthus. International Journal of Systematic and Evolutionary Microbiology, 51:17-26.

45. Egamberdieva, D. (2010). Growth response of wheat cultivars to bacterial inoculation in calcareous soil. Plant Soil and Environment, 56(12):570-573.

46. Estiyar, H.K.; khoei, F.B. and Behrouzyar, E.K. (2014). The effect of Nitrogen biofertilizer on yield components of white bean (Phaseolus vulgaris (cv) Dorsa). International Journal of Biosciences, 4(11):217.

47. Falk, E.C.; Dobereiner, J.; Johnson, J.L. and Krieg, N.R. (1985). Deoxyribonucleic acid homology of Azospirillum amazonense and emendation of the description of the genus Azospirillum.International Journal of Systematic Bacteriology, 35:117-118.

48. Falk, E.C.; Johnson, J.L.; Baldani, V.L.D.; Dobereiner, J. and Krieg, N.R. (1968). Deoxyribonucleic and ribonucleic acid homology studies of the genera Azospirillum and Conglomeromonas. International Journal of SystematicBacteriology, 36:80-85.

49. Fries, N. (1973). Effects of volatile organic compounds on the growth and development of fungi. Transactions of the British Mycological Society, 60(1):1-21.

50. Gadagi, R.S.; Krsihnraj, P.U.; Kulkami, J.H. and Sa, T.M. (2002). Biodiversity of Azospirillum in the ornamental rhizosphere soils of Kamataka. Confronting new realities in the $21^{\text {st }}$ century. In: Proceedings of the world soil science congress. Sym. 09, Bangkok, Thailand, pp 274.

51. Gadagi, S.; Ravi, P.; Krishanraj, U.; Kulkarni, J.H. and Tongmin, S.A. (2003). The effect of combined Azospirillum inoculation and Nitrogen fertilizer on plant growth promotion and yield response of the plant flower Gaillardia pulchella. Scientia Horticulturae, 100(1-4):323-332. 
52. Gaulke, L.S.; Henry, C.L. and Brown, S.L. (2002). Nitrogen fixation and growth response of Alnus rubra following fertilization with urea or biosolids. Scientia Agricola (Piracicaba, Brazil), 3(4):361-369.

53. Gaur, A.C. and Alagawadi, A.R. (1989). Interaction of Nitrogen fixation and Phosphate solubilizing microorganisms on crop productivity. Plant Microbe Interactions Proc. Theme Symposium Bot. section, ISCA, Bangalore, pp 35-46.

54. Govindan and Bagyaraj, D.J. (1995). Field response of wetland rice to Azospirillum inoculation. Journal of Soil Biology and Ecology, 15:17-22.

55. Graham, P.H. and Vance, C.P. (2000). Nitrogen fixation in perspective: an overview of research and extension needs. Field Crops Research, 65:93-106.

56. Hartmann, A.; Fu, H.A. and Burris, R.H. (1988). Influence of amino acid on Nitrogen fixation ability and growth of Azospirillum species. Applied Environmental Microbiology, 54(1):87-93.

57. Hemavathi, M. (1997). Effect of organic manures and biofertilizers on growth and productivity of Chrysanthemum (Chrysanthemum morifolium ramat) cv Local Yellow. M.Sc thesis, Division of Horticulture, University Agricultural Sciences, Bangalore (India).

58. Herridge, H.F.; Peoples, M. and Boddey, R.M. (2008). Global inputs of biological Nitrogen fixation in agricultural systems. Plant and Soil, 311:1-18.

59. Heulin, T.; Rashman, M.; Omar, A.M.N.; Rafidison, Z.; Pierrat, J.C. and Balandreau, J. (1989). Experimental and mathematical procedures of comparing Nitrogen fixing efficiencies of rhizosphere diazotrophs. Journal of Microbiology Methods, 9:163-173.

60. Hungria, M. and Franco, A.A. (1963). Effects of high temperature on nodulation and Nitrogen fixation by Phaseolus vulgaris (L.). Plant Soil, 49:95-102.

61. Jayasudha, T.; Rangeshwaran and Vajid, N. (2010). Relationship between Indole Acetic Acid production of fluorescent Pseudomonas and plant growth promotion. Journal of Biological Control, 24:349-359.

62. Jofre, E.; Mori, G.; Castro, S.; Fabra, A.; Rivarola, V. and Balegno, H. (1996). 2,4 Dichlorophenoxyacetic acid affects the attachment of Azospirillum brasilense cd to maize roots. Toxicology, 107(1):9-15.

63. Johnstone, D.S. (1974). Genus I. Azotobacter 1901, 567.

64. GenusII. Azomonas Winogradsky 1938, 391. In: Bergey’s Manual of Determinative Bacteriology $8^{\text {th }}$ Edition (eds. Burhanan, R.E. and Gibbons, N.E.). Williams and Wilkins, Baltimore, pp 254-256.

65. Kandil, A.A.; El Hindi, M.H.; Badawi, M.A.; El Morarsy, S.A. and Kalboush, F.A.H.M. (2011). Response of wheat to rates of Nitrogen, biofertilizers and land leveling. Crop and Environment, 2(1):46-51.

66. Kavimandan, S.K.; Lakshmi-Kumari, M. and Subba Rao, N.S. (1978). Non-symbiotic nitrogen fixing bacteria in the rhizosphere of wheat, maize, sorghum. Proceedings Indian Academy of Sciences, 87:299-302.

67. Khakipour, N.; Kavazi, K.; Mojallali H.; Pazira, E. and Asadirahmani, H. (2006). Production of Auxin hormone by Fluorescent Pseudomonas.American-EurasianJournal of Agriculture and Environmental Science, 4:687-692.

68. Khammas, K.M.; Ageron, E.; Grimontand, P.A.D. and Kaiser, P. (1989). Azospirillum irakense sp. Nov. a Nitrogen fixing bacterium associated with rice roots and rhizosphere soil. Research in Microbiology, 140:679693.

69. Khare, E. and Arora, N.K. (20100. Effect of Indole-3-Acetic Acid (IAA) produced by Pseudomonas aeruginosa in suppression of charcoal rot disease of chickpea. Current Microbiology, 61:64-68.

70. Kindu, B.S. and Gaur, A.C. (1980). Effect of Nitrogen fixing and Phosphate solubilizing microorganisms single and composite inoculants on cotton. Indian Journal of Microbiology, 20(3):225-229.

71. Kolb, W. and Martin, P. (1985). Response of plant roots to inoculation with Azospirillum brasilense and to application o Indole Acetic Acid. In: Azospirillum III Genetics, Physiology, Ecology, Klingmuller W (ed.) Springer-Verlag, Berlin, pp 215-221.

72. Kravchenko, I.K. and Doroshenko, E.V. (2003). Nitrogen fixing activity in peat soils from a raised bogs. Microbiology, 72:98-102.

73. Kucey, E.; Liu, Z. and Kloppstech, K. (1993). Expression of heat shock proteins during development of barley. Plant Molecular Biology, 23:111-122.

74. Kukreja, K.; Suneja, S.; Goyal, S. and Narula, N. (2004). Phtyohormone production by Azotobacter. Themofisher Scientific, 25(1):

75. Kumar, A.; Sharma, S. and Mishra, S. (2009). Application of Farmyard Manure (FYM) and vermicompost of Vegetative and generative. Characterstics of Jatropha curcas.Journal of Phytolpathology, 1(4):206-212.

76. Li, D.Y.; Eberspacher, J.; Wanger, B.; Kuntzer, J. and Lingens, F. (1991). Degradation 2,4,6 trichlorophenol by Azotobacter sp. "Strain GP1." Applied and Environmental Microbiology, 57(7):1920-1928. 
77. Libbert, V. and Risch, H. (1969). Interactions between plants and epiphytic bacteria regarding their auxin metabolism. Isolation and identification of the IAA producing and destroying bacteria from pea plants. Plant Physiology, 22:51-58.

78. Lindow, S.E. and Brandl, M.T. (2003). Microbiology of the phyllosphere. Applied Environmental and Microbiology, 69:1875-1883.

79. Line, M.A. and Loutit, M.W. (1973). Nitrogen fixation by mixed cultures of aerobic and anaerobic microorganisms in an aerobic environment. Journal of Microbiology, 74:179-180.

80. Maathuis, F.J.M. (2009). Physiological functions of mineral macronutrients. Current opinion in Plant Biology, 12:250-258.

81. Magalhaes, F.M.M.; Patniqin, D. and Dobereiner, J. (1981). Infection of maize roots by Azospirillum spp. In: Associative Nitrogen fixation (eds.) Vose, P.B. and Ruschel, A.P., CRC Press, Boca Raton, FI, pp 201-204.

82. Mahmoud, R.R.; Popov, Y.; Khavazi, K. and Asadi Rahmani, H. (2010). Genetic diversity and efficiency of Indole Acetic Acid production by the isolates of fluorescent Pseudomonas from Rhizosphere of rice. AmericanEurasian Journal of Agriculture and Environmental sciences, 7:103-109.

83. Maleki, M.; Mostafee, S.; Mohammad, Z. and Farzenah, M. (2010). Characterization of Pseudomonas fluorescence strains CV-6 isolated from cucumber rhizosphere in varamin as a potential biocontrol agent. Australian Journal of Crop Science, 4(9):676-683.

84. Malleswari, D. and Bagyanayana, G. (2013). In vitro screening of rhizobacteria isolated from the rhizosphere of medicinal and aromatic plants for multiple plant growth promoting activities. Journal of Microbiology and Biotechnology Research, 3(1):84-91.

85. Mendes, R.; Garbeva, P. and Raaijmarkers, J.M. (2013). The rhizosphere microbiome: significance of plant beneficial, plant pathogenic and human pathogenic microorganisms. FEMS Microbiology Reviews, 35(5):634663.

86. Meunchang, S.; Panichsakpatana, S. and Weaver, R.W. (2006). Tomato growth in soil amended with sugar mill by-product compost. Plant and Soil, 280(1-2):171-176.

87. Michiels, K.; Verreth, C. and Vanderleyden, J. (1990). Azospirillum lipoferum and Azospirillum brasilense surface polysaccharide mutants are affected inflocculation. Journal of Applied Bacteriology, 69:705-711.

88. Mihustin, E.N. and Shil'nikova, V.K. (1968). Biologisheskaya fiksatsiya atmosfernogo azota (Biological fixation of atmospheric Nitrogen), Moscow: Nauka.

89. Mosolov, I.V.; Rampe, H.R. and Alendandrowakya, V.A. (1959). The interactions of higher plants and microorganisms. Ag. Rostholog (USSR), 3:425-450.

90. Mrkovac, N. and Milic, V. (2001). Use of Azotobacter chroococcum potentially useful in agricultural application. Annals of Biology, 51:145-158.

91. Mulder, E.G. and Brotonegoro, S. (1974). Free living heterotrophic Nitrogen fixing bacteria of the genus Azotobacter. "In the Soil Biology of Nitrogen fixation" (ed. Quispel, A). North Holland, Amsterdam, pp 37-85.

92. Narania, K. and Reddy, S.M. (1979). In vitro production of IAA by five hyphomycetes. Geobios, 6:260:262.

93. Naseri, R.; Azadi, S.; Rahimi, M.J.; Maleki, A. and Mirzaei, A. (2013). Effect of inoculation with Azotobacter chroococcum and Pseudomonas putida on yield and some of the important agronomic traits in barley (Hordeum vulgare L.). International Journal of Agronomy and Plant Production, 4(7):1602-1610.

94. Nelson, L.M. (2004). Plant growth promotes rhizobacteria (PGPR). Prospects for new inoculants. Online Crop Management, 3(1):301-305.

95. O’Brien, M.R. and Maier, R.J. (1989). Molecular aspects of the energetic of the Nitrogen fixation in the Rhizobium legume symbiosis. Biochimica et Biopysica Acta, 974:229-246.

96. Ocampo, J.A.; Barea, J.M. and Monotoya, E. (1975). Interactions between Azotobacter and Phosphobacteria and their establishment in rhizosphere as affected by soil fertility. Canadian Journal of Microbiology, 21(8):1160-1165.

97. Ojaghloo, F.; Farahvash, F.; Hassanzadeh, A. and Pouryusef, M. (2007). Effects of inoculation Azotobacter and Barvar Phosphate fertilizers on yield of Safflower. Journal of Agricultural Sciences, Islamic Azad University, Tabriz Branch, 25:30.

98. Okon, Y. (1985). Azospirillum as a potential inoculant for agriculture. TrendsBiotechnology, 3:223-228.

99. Okon, Y. and Labandera-Gonzalez, C.A. (1994). Agronomic applications of Azospirillum. In: Ryder, M.H.; Stephens, P.M. and Brown, G.D. (eds.) improving plant productivity with rhizosphere bacteria. Commonwealth scientific and Industrial Research Organisation, Adelaide, pp 214- 248.

100.Omay, S.H.; Schmidt, W.A.; Martin, P. and Bangertti (1993). Indole Acetic Acid production by the rhizosphere bacterium Azospirillum brasilense cd under in vitro conditions. Canadian Journal of Microbiology, 24:734-742. 
101.Palleroni, N.J. (1986). Taxonomy of Pseudomonas. In the Bacteria- A Treatise on structure and function. The Biology of Pseudomonas (ed) Sokatch, J.R. Acadamic Press. Volume 10.

102.Peng, G.; Wang, H.; Zhang, G.; Hou, W.; Liu, Y.; Wang, E. T. and Tan, Z. (2006). Azospirillum melin is sp. Nov. a group of diazotrophs isolated from tropical molasses. International Journal of Systematic and Evolutionary Microbiology, 56:1263-1271.

103.Plazinski, J. and Rolfe, B.G. (1985). Influence of Azospirillum strains on the nodulation of clovers by Rhizobium strains. Applied Environmental Microbiology, 49:984-989.

104.Polyanskaya, L.M.; Vendine, O.T.; Lysak, L.V. and Zvyagintsev, D.G. (2002). The growth promoting effect of Beijerinckia mobilis and Clostridium species cultures on some agricultural crops. Microbiology, 71(1):109-115.

105.Rahim, A.M.A.; Baghadani, A.M. and Abdalla, M.H. (1983). Studies on the fungus flora in the rhizosphere of sugarcane plants. Micropathologia, 81(3):183-186.

106.Rai, S.N. and Caur, A.C. (1998). Characterization of Azotobacter spp. and effect of Azospirillum lipoferum on the yield and Nitrogen uptake of crop wheat. Plant and Soil, 109:131-134.

107.Ramanan, R. and Kino, H.S. (2016). Algae-bacteria interactions: Evolution, ecology and emerging applications. Biotechnology Advances, 34(1):14-29.

108.Ramezanpour, M.R. (2011). Biochemical characteristic and genetic diversity of fluorescent Pseudomonas isolated from rice rhizosphere in North Iran. American-Eurasian Journal of Agriculture and Environmental Sciences, 10:180-185.

109.Rangaswami, O. (1988). Soil plant inter-relationship. Indian Phytopathology, 41:165-172.

110.Rao, A.V. and Venkateswaralu, B. (1985). Most probable number of Azospirillum associated with roots of inoculated pearl millets. Plant soil, 88:153-196.

111.Rastetter, E.; Vitousek, P.; Field, C.; Shaver, C.; Herbert, D. and Agren, G. (2001). Resource optimization and symbiotic Nitrogen fixation. Ecosystems, 4:369-388.

112.Reddy, P.K. and Reddy, M.S. (2009). Biochemical and PCR-RAPD characterization of Pseudomonas fluorescens produced antifungal compounds inhibit the rice fungal pathogens in vitro. Journal of Pure and Applied Microbiology, 3(1):1-4.

113.Riviere, J. (1963). Rhizosphere et croissant du blé. Annalaes of Agronomiquis, 14:619-622.

114. Roal, B.V. and Vaidya, B.V. (1988). The occurrence of Trichoderma harzianum in the rhizosphere of sugarcane (Saccharum officinarium L.) cultivar co. 419. Indian Botanical Reporter, 7:39-42.

115.Saikia, S.P.; Jain, V.; Khetarpal, S. and Aravind, S. (2007). Dinitrogen fixation activity of Azospirillum brasilense in maize (Zea mays). Current Science, 93(9):1296-1299.

116.Schortemeyer, M.; Atkin, O.K.; Mc Farlane, N. and Evans, J.R. (2002). Nitrogen fixation by Acacia species increases elevated atmospheric carbondioxide. Plant Cell Environment, 25:567-579.

117.Sengupta, R.K. (1990). Isolation of Azotobacter from root and rhizospheric soil samples of grasses and detection of their phages from its natural ecosystem. M.Sc. Dissert, Department of Botany, Kalyani University, India.

118.Shank, Y.U.; Demin, O. and Bogachev, A.V. (2005). Respiratory protection nitrogenase complex in Azotobacter vinelandii success. Biological Chemistry, 45:205-234.

119.Singh, K.; Babu, S.; Avasthe, R.K.; Yadav, G.S.; Chettri, T.K.; Phempunadi, C.D. and Chatterjee, T. (2015). Bacterial inoculation effect on soil biological properties, growth, grain yield, total phenolic and flavonoids contents of common buckwheat (Fagopyrum ecsulentum Moench) under hilly ecosystem of North East India. African Journal of Microbiology Research, 9(15):1110-1117.

120. Soleimanzadeh, H. and Gooshchi, F. (2013). Effects of Azotobacter and Nitrogen chemical fertilizer on yield components of wheat (Triticum aestivum). World Applied Science Journal, 21(8):1176-1180.

121.Sprent, J.I. (2001). Nodulation in legumes. Annals of Botany, pp 1-9.

122.Sridhar, R. (1996). Studies on the interaction of Pseudomonas fluorescens Migula with certain beneficial and harmful microorganism in the rhizosphere of some crop plants. Ph.D. Thesis. Tamil Nadu Agricultural University, Coinbatore.

123. Subramoney, N. and Araham, A. (1962). A note on the non- symbiotic Nitrogen fixation in the red loam soil. Science and Culture, 28:239-240.

124. Suthar, S. (2009). Impact of vermicompost and composted farmyard manure on growth and yield of garlic (Allium atium L.) field crop. Internatinal Journal of Plant Production, 3(1):27-38.

125.Tal, S. and Okon, Y. (1985). Production of the reserve material poly-D-ß-hydroxybutyrate and its function in Azospirillum brasilense cd. Canadian Journal of Microbiology, 31:608-613. 
126.Tarrand, J.J.; Kreig, N.R. and Dobereiner, J. (1978). A toxonic study of the spirillum lipoferum grp, with the descriptions of a new genus, Azospirillum gen. Nov. and two species, Azospirillum brasilense (beijerinck) comb. Nov. Canadian Journal of Microbiology, 24; 967-980.

127.Taylor, A.C.; Mastronicola, T.A. and Mc Glathery, K.J. (2003). Nitrogen fixation and Nitrogen limitation of primary production along a natural marsh chronosequence. Ecosystem Ecology, 136:431-438.

128.Thapliyal, R.; Chaukiyal, S.P. and Polhriyal, T.C. (2009). Effect of Nitrogen and Phosphorus doses on the Nitrogen fixation activity of the Albizia lebbeck plants in the nursery. Improvement and Culture of the Nitrogen fixing trees. NFT News, 11(1):1-4.

129.Troxhler, J.; Zeha, M.; Natsch, A.; Nivergelf, J.; Keel, C. and Defago, G. (1998). Transport of biocontrol Pseudomonas fluorescens through $2.5 \mathrm{~m}$ deep outdoor lysimeters and survival in effluent water. Soil Biology and Biochemistry, 30:621-631.

130.Turco, R.F. and Sadowsky, W.J. (1995). Understanding microflora of bioremediation. In: Skipper, H.D. and Turco, R.F. (eds.), Bioremediation: Science and Applications. Soil Science (special publication). Madison WI: Soil Science Society of American Journal, 43: 87-103.

131.Vadakattu, G. and Paterson, J. (2006). Free living bacteria lift soil nitrogen supply. Farming Ahead, 169:40.

132.Vasantharajan, W. and Bhat, J.V. (1968). Interrelations of microorganisms and mulberry. II. Phyllospher microflora and Nitrogen fixation in leaf and root surfaces. Plant and Soil, 28(2):258-267.

133.Vela, G.R. (1974).Survival of Azotobacter in dry soil. Applied Microbiology, 28(1):77-90.

134.Vitousek, P.M.; Cassman, K.; Cleveland, C.; Crews, T. and Field, C.B. (2002). Towards an ecological understanding of biological Nitrogen fixation. Biogeochemistry, 58:1-45.

135. Vojinoviv, Z. (1961). Microbiological properties of main types soil in Serbia for Nitrogen cycling. Journal for Scientific Agricultural Research, 43:2-25.

136. Wall, L.G.; Hellesten, A. and Huss-Danell, K. (2000). Nitrogen, Phosphorus and the ratio between them affect the nodulation in Alnus incana and Wfolium prattense. Symbiosis, 29:91-105.

137.Wang, F.; Li, Z.; Xia, H.; Zou, B.; Liu, J. and Zhu, W. (2010). Effects of Nitrogen fixing and non-Nitrogen tree species on soil properties and Nitrogen transformation during forest restoration in Southern China. Soil Science and Plant Nutrition, 56(2):297-306.

138. Watanabe, K. and Hayano, K. (1993). Distribution and identification proteolytic Bacillus species in paddy field soil under rice cultivation. Canadian Journal of Microbiology, 39:674-680.

139.Weber, O.B.; Baldani, V.L.D.; Teixeira, K.R.S.; Kirchhof, G.; Baldani, J.J. and Dobereiner, J. (1999). Isolation and characterization of diazotrophic bacteria from banana and pineapple plants. Plant Soil, 210:103-113.

140.Whallon, J.H.; Acker, G.F. and Khawas, H.E.L. (1985). Electron microscopy of young wheat roots inoculated with Azospirillum. In: Azospirillum, Genetics, Physiology and Ecology (eds.) Klingmuller, W. SpringerVerlag, Berlin, pp223-239.

141.Wu, L.; Wang, H.; Zhang, Z.; Lin, R.; Zhang, Z. and Lin, W. (2011). Comparative metaproteomic analysis on conconsecutively Rehmannia glutinosa-monoculture rhizosphere soil. PLOS ONE, 6(5):e20611.

142.Wu, S.C.; Cao, Z.H.; Li, Z..G.; Cheung, K.C. and Wong, M.H. (2005). Effects of biofertilizers containing Nitrogen fixer, $\mathrm{P}$ and $\mathrm{K}$ solublizers and Arbuscular Mycorrhizal fungi on maize growth: a greenhouse trial. Geoderma, 125:155-166.

143.Xie, C.H. and Yokota, A. (2005). Azospirillum Oryzae sp Nov, a Nitrogen fixing bacterium isolated from the roots of rice plant Oryzae sativa. International Journal of Systematic and Evolutionary Microbiology, 55:14351438.

144.Yan, Z.; Reddy, M.S.; Ryu C.M.; Inroy, M.C.; Wilson, M. and Kloepper, J.W. (2002). Induced systemic resistance against tomato late blight elicited by plant growth promoting rhizobacteria. Phytopathology, 92:13291333. 